\title{
Some Lessons Learned on Early Survival and Growth of Containerized, Locally-Sourced Ponderosa Pine Seedlings in the Davis Mountains of Western Texas, US
}

\author{
Lance A. Vickers ${ }^{1, *}$, James Houser ${ }^{2}$, James Rooni ${ }^{2}$ and James M. Guldin ${ }^{3}$ \\ 1 School of Natural Resources, University of Missouri, Columbia, MO 65211, USA \\ 2 Texas A\&M Forest Service, College Station, TX 78723, USA; jhouser@tfs.tamu.edu (J.H.); \\ jrooni@tfs.tamu.edu (J.R.) \\ 3 Southern Research Station, USDA Forest Service, Hot Springs, AR 71902, USA; jguldin@fs.fed.us \\ * Correspondence: lance.vickers@mizzou.edu
}

Received: 15 February 2019; Accepted: 13 March 2019; Published: 16 March 2019

\begin{abstract}
The ponderosa pine forests in the Davis Mountains of western Texas recently experienced a major mortality event caused, in part, by an extended regional drought that predisposed trees and stands to mortality from both western pine beetle and wildfires. The loss of many overstory pines and the scarcity of natural ponderosa pine regeneration pose a considerable challenge to restoration. A commissioned study investigated artificial regeneration using containerized ponderosa pine seedlings with multiple planting seasons and vegetation management alternatives. Early survival was statistically greater for dormant season plantings than monsoon season plantings. Vegetation management treatments influenced early growth, survival, and herbivory rates. Physical weed control, which consisted of fibrous weed mats around the base of planted seedlings, showed early advantages over some vegetation management treatments in growth, survival and herbivory deterrence, but all vegetation management treatments had similar survival and herbivory results after 2.5 years. Early survival was poor in all treatments, mainly due to herbivory, which was identified as the principal short-term obstacle to artificial regeneration of ponderosa pine in the Davis Mountains. The larger question regarding feasibility of recovery in this isolated population, particularly if local climatic conditions become increasingly unfavorable, remains.
\end{abstract}

Keywords: restoration; regeneration; reforestation; drought; wildfire; herbivory

\section{Introduction}

Ponderosa pine (Pinus ponderosa Laws.) is one of the most important and widely distributed pines on the North American continent [1]. The largest ponderosa pine population in Texas occurs in the Davis Mountains (Figure 1), much under ownership or conservation easement by The Nature Conservancy's (TNC) Davis Mountains Preserve (DMP). This isolated population is the southern-most extent of the species in the United States, although some varietal taxonomic questions remain [2,3]. The nearest conspecific neighbors are a minor population in the Guadalupe Mountains, approx. $150 \mathrm{~km}$ away, and a major population approx. $250 \mathrm{~km}$ away in the Sacramento Mountains of New Mexico [4]. 


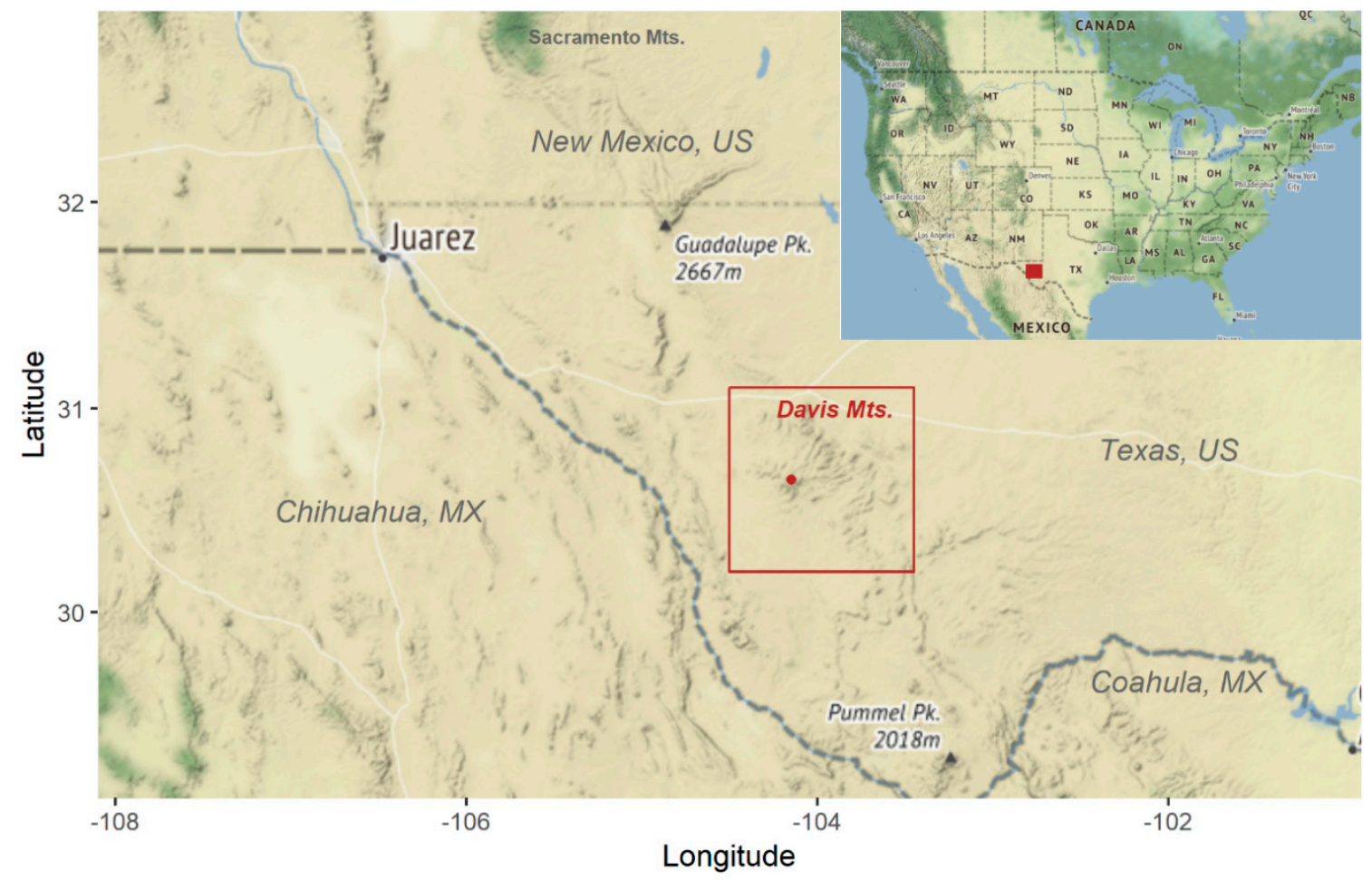

Figure 1. Study location (point) within the Davis Mountains (box) of western Texas, USA.

The Davis Mountains $\left(-104^{\circ} 06^{\prime} \mathrm{W}, 30^{\circ} 42^{\prime} \mathrm{N}\right.$, Figure 1) are approx. 35 million years old, predominantly igneous in origin, and range in elevation from approx. 1500-2500 $\mathrm{m}$. They occur within the Trans-Pecos Isolated Mountain Ranges Subsection (321Ab) of the Chihuahuan Semi-Desert Ecological Province [5]. The Köppen climate type is cold semi-arid, with average minimum temperatures ( $2100 \mathrm{~m}$ elevation) ranging from $0-15{ }^{\circ} \mathrm{C}$ (January to July) and average maximum temperatures ranging from $12{ }^{\circ} \mathrm{C}$ in January to $29^{\circ} \mathrm{C}$ in June. Annual precipitation includes $483 \mathrm{~mm}$ of rainfall and $127 \mathrm{~mm}$ of snowfall on average with the majority occurring in a distinct monsoon pattern from June-September.

Vegetation communities are transitional, varying from Chihuahuan grasslands to sky island conifer-dominated relict forests with increasing elevation [6]. At mid-elevations piñon woodlands and oak-piñon-juniper woodlands dominate, whereas at higher elevations ponderosa pine is more prevalent and mixed conifer-hardwood assemblages dominate [7-9].

Across much of the range of ponderosa pine, and particularly in the Southwest, "megadisturbances" have reduced vigor in many conifer-dominated stands and contributed to species conversion, stand replacement, or loss of forest in others [10,11]. These are usually the confluence of extreme ecological events in forest stands and landscapes that are accentuated by difficult geography, and exacerbated by changes in historic patterns of fire. All of those elements have acted as stressors to forest health and vigor over the past century in the DMP. Fire-return intervals in the region averaged approx. 5 years before 1937, but 20-40 years after that [12]. As a result, DMP forests underwent a densification process that started near the turn of the 20th century [12,13]. Piñon-juniper (Pinus cembroides [Zucc.]-Juniperus sp.) density increased from approx. 250 trees ha ${ }^{-1}$ in 1890 to over 2820 trees $\mathrm{ha}^{-1}$ in 2005 [13]. Moreover, the ability to manage these stands by thinning to reduce densities and promote individual tree vigor is constrained by the absence of local timber markets; no sawmill is reported within nearly $500 \mathrm{~km}$ [14].

In the 1990s, these dense forests experienced an extended period of elevated temperatures and drought $[15,16]$. In 2004, the ponderosa pine population was estimated to be about 336 trees ha ${ }^{-1}$, on parts of the DMP [17]. Wildfires burned through several stands across the Davis Mountains in 
2011-2012. Along with pre-existing and ongoing bark beetle attacks, those wildfires contributed to the loss of over half the ponderosa pine population based on Texas A\&M Forest Service (TFS) inventories.

With some recent exceptions, surveys of post-wildfire cone crops on surviving mature trees have reported poor cone production. This has, in part, led to few and scattered naturally-occurring ponderosa pine seedlings becoming established post-wildfire. While the establishment of ponderosa pine reproduction cohorts is often sporadic in the southwestern US [18], scarcity of reproduction following high-severity fires increases the potential risk of transformation to alternative vegetation states [19]. Given the sporadic establishment tendency of ponderosa pine, which requires specific conditions across several consecutive years, reproduction densities may yet improve with periodic favorable climatic windows. However, long-term climatic conditions may reduce the frequency of those favorable windows for seedling establishment. Regeneration difficulties due, in part, to disturbance-climate interactions can lead to range retractions at the trailing edge of a species range [20]. Because ponderosa pine is the primary high-canopy tree species in the Davis Mountains, the ecological consequences of persistent regeneration difficulties and mortality events could be severe [21,22].

To evaluate alternatives for restoration and recovery of ponderosa pine in the DMP, TFS initiated "Operation Ponderosa", in cooperation with TNC and other partners. A primary goal of Operation Ponderosa was to foster ponderosa pine regeneration, by both natural and artificial means. Because science-based silvicultural guidelines are not available for the Davis Mountains, several questions regarding the best practices for artificial regeneration exist. These questions include the appropriate time of year for planting, and the availability of early cultural treatments that promote survival and growth of planted seedlings. Research has shown early survival and growth benefits for ponderosa pine seedlings following vegetation management treatments that limit herbaceous competition $[1,23]$. To begin addressing those questions, a study on artificial regeneration of ponderosa pine in the DMP was commissioned. This study used locally-sourced containerized seedlings raised by TFS and tested a set of low-cost vegetation management options that could feasibly be applied by a hand crew in the remote, rugged terrain. The specific goals were to explore the efficacy of two different planting seasons (dormant and monsoon) and three vegetation management options (fibrous weed mats, herbicide, and none) on planted seedling survival and growth. Because localized group structures within uneven-aged stands are commonly observed in the DMP and across frequent-fire forests of the US Southwest [10] a cluster-planting pattern was used to mimic those grouped patterns.

\section{Materials and Methods}

\subsection{Study Sites}

Three stands formerly dominated by ponderosa pine within the DMP were used for the study area (Table 1). These stands all had some degree of ponderosa pine mortality during the wildfires in 2011-2012 and subsequently received a thinning treatment in 2015 to reduce the density of surviving ponderosa pine competitors not adversely affected by the wildfires (primarily Juniperus and Quercus). The residual basal area in the three stands averaged $3.5 \mathrm{~m}^{2} \mathrm{ha}^{-1}$ with ponderosa pine the chief contributor, making up approx. $65 \%$. Other common species were gray oak (Q. grisea [Liebmann]), Emory oak (Q. emoryi [Torr.]), alligator juniper (J. deppeana [Steud.]), and piñon pine (P. cembroides [Zucc.]). Other comparatively rare oaks were present along with black cherry (Prunus serotina [Ehr.] var. virens) and Texas madrone (Arbutus xalapensis [Kunth]). Soils were uniform within each stand and predominantly of the Loghouse association (Loamy-skeletal, mixed, superactive, mesic Typic Haplustalfs); soils [24]. The Loghouse association typically is a deep ( $>200 \mathrm{~cm}$ to restriction) and well-drained loam with low available water storage in the profile. 
Table 1. Overview of Davis Mountains Preserve study stands and their condition at the time of planting, number of ten-tree planting groups for planting season $\cdot$ vegetation management ${ }^{\text {a }}$ treatment combination in each stand, and total number of seedlings ${ }^{c}$ planted for each treatment combination in each stand. SE refers to standard error.

\begin{tabular}{lccc}
\hline & Stand A & Stand B & Stand C \\
\hline Stand area & 5.8 ha & 14.6 ha & 17.2 ha \\
Residual basal area & $2.8 \mathrm{~m}^{2} \mathrm{ha}^{-1}$ (SE: 0.6) & $3.4 \mathrm{~m}^{2} \mathrm{ha}^{-1}(\mathrm{SE}: 0.6)$ & $4.4 \mathrm{~m}^{2} \mathrm{ha}^{-1}$ (SE: 1.0$)$ \\
Ponderosa pine composition & $60 \%$ & $50 \%$ & $86 \%$ \\
Dormant.CWC planting groups & 5 & 5 & 5 \\
Dormant.NWC planting groups & 5 & 5 & 5 \\
Dormant.PWC planting groups & 5 & 5 & 5 \\
Monsoon·CWC planting groups & - & 4 & $5 \mathrm{~b}$ \\
Monsoon·NWC planting groups & - & 4 & 5 \\
Monsoon·PWC planting groups & - & 4 & 4 \\
$\sum$ Dormant planting groups & 15 & 15 & 15 \\
$\sum$ Dormant Seedlings (1-0, D40) & 150 & 150 & 150 \\
$\sum$ Monsoon planting groups & - & 12 & 14 \\
$\sum$ Monsoon Seedlings (2-0, D60) & - & 120 & 137 \\
\hline$\sum$ Planting groups & 15 & 27 & 29 \\
$\sum$ Seedlings & 150 & 270 & 287 \\
\hline
\end{tabular}

${ }^{a}$ NWC $=$ no weed control, $\mathrm{CWC}=$ chemical weed control, $\mathrm{PWC}=$ physical weed control. ${ }^{\mathrm{b}} 1$ planting group consisted of only 7 seedlings. ${ }^{\mathrm{C}}$ Locally-sourced ponderosa pine containerized seedlings from a single seed crop were used in all treatments, D40 containers were used for the 1-0 dormant season planting, D60 containers were used for the 2-0 monsoon season planting.

\subsection{Study Design}

The study was a fully randomized unbalanced incomplete block design where treatment combinations were assigned at random to individual planting groups (i.e., plots) within each of three stands. Each planting group comprised 10 seedlings cluster-planted within a 0.008-ha area. Planting group locations within each stand were randomly determined but constrained to avoid roads, streams, large residual trees, or severe planting obstacles (large slash piles, excessive boulder/rock cover). The two main effect treatments were planting season with two levels (dormant or monsoon) and vegetation management with three levels (chemical, physical, or none). The dormant season-vegetation management treatment combinations were replicated five times in each stand. The study was an unbalanced incomplete block because monsoon season vegetation management treatment combinations were replicated fully only four times and only in two stands. This was due to unexpected difficulty with stand access and poor seedling survival in the nursery ahead of the monsoon season planting.

The two planting season treatment levels used nursery-grown seedlings from a single 2014 local seed collection effort by TFS. For the dormant season planting (November 2015), containerized (1-0, D40) seedlings were planted to a "first-green" depth, i.e., to the base of live foliage. The 450 dormant season seedlings in the study had an average root collar diameter of $0.4 \mathrm{~cm}$ (SE: 0.009) and stem height of $13.8 \mathrm{~cm}$ (SE: 0.3) with an average root:shoot ratio of approx. 2:1 at the time of planting. Seedlings intended for the monsoon planting remained in the nursery longer, requiring larger D60 containers to carry the seedling through a second growing season in the nursery. The monsoon season treatment (late August 2016) planted these older (2-0), larger containerized seedlings to container depth due to rocky soils at depth, i.e., the surface of the soil in the container matched the soil surface at the planting spot. The 257 monsoon season seedlings had an average root collar diameter of $0.6 \mathrm{~cm}$ (SE: 0.02) and stem height of $18.1 \mathrm{~cm}$ (SE: 0.7), with an average root:shoot ratio of approx. 2:1, although there was considerable variation in height, diameter, and overall condition of these older seedlings at the time of planting. 
The three vegetation management treatment levels included a no weed control (NWC) treatment as an experimental control and two herbaceous weed control treatments: physical weed control (PWC) and chemical weed control (CWC). The PWC treatment consisted of a $0.4 \mathrm{~m}^{2}$ fibrous mat installed around each seedling at the time of planting. The fibrous mats were installed over any existing herbaceous vegetation (some clearing was required when excessive) and secured to the ground using several $15.2 \mathrm{~cm}$ landscape staples along the mat edges and near the base of each seedling. The CWC treatment consisted of a backpack application of Oust ${ }^{\circledR} \mathrm{XP}$ (sulfometuron methyl, Bayer CropScience LP, Research Triangle Park, Durham, NC, USA) at a rate of $0.14 \mathrm{~kg} \mathrm{ha}^{-1}\left(2 \mathrm{oz} \mathrm{ac}^{-1}\right.$-the lowest labeled rate for herbaceous weed control) in $187.1 \mathrm{~L} \mathrm{ha}^{-1}$ water. The herbicide was applied to the entire 0.008-ha area around a planting group. For convenience, a single application in April 2016 was used for both the dormant and monsoon season plantings. For the dormant planting, application timing was consistent with labeled recommendations for post-planting release. For the monsoon planting, the application timing was, in essence, site-preparation. On follow-up visits, the herbicide effect on competing herbaceous vegetation was noticeable but inconsistent, and complete control of competing vegetation was not achieved for any planting group.

\subsection{Data Collection}

Immediately following out-planting, ground line diameter and stem height were measured on all planted seedlings. Initial survival surveys on the dormant plantings were conducted approx. 1 month (December 2015) following planting, and again after 3, 5, 6, 7, 9, 13, 15, 17, and 29 months (April 2018). Initial survival surveys on the monsoon planting were conducted approx. 4 months (December 2016) following planting, and again after 6, 8, 12, and 20 months (April 2018). Survival surveys recorded the apparent cause of death when applicable. Recorded causes of death included desiccation and herbivory. Desiccation was assigned to intact dead seedlings with no evidence of disturbance. Herbivory was assigned to dead seedlings that were visibly browsed (above or below ground) or missing from the planting location entirely. First-year growth measurements (height, ground line diameter) were completed during the 12- and 13-month surveys for the monsoon and dormant plantings, respectively.

\subsection{Data Analysis}

All statistical analysis used R version 3.3.2 [25]. An $\alpha$ of 0.05 benchmarked statistical significance.

\subsubsection{Survival}

The average proportion of surviving seedlings in a planting group after one year was modeled as a function of vegetation management and planting season (with three and two levels respectively) and their interaction as fixed effects, along with stand as a random effect intercept (Table 2, Model 1) using mixed-effects logistic regression fit by maximum likelihood via the lme4 package [26]. However, poor first-year monsoon survival ( $<1 \%$ after 1 year), left little utility in analyzing differences among monsoon season vegetation management treatment combinations. For this reason, planned monsoon season survival and growth analyses (including the model above) were abandoned and the study design was simplified to consider only dormant season plantings. Prior to doing so, a likelihood ratio test confirmed that there was not a statistically significant planting season-vegetation management interaction $(p=0.20)$. Given the non-significant interaction term, Type II Wald tests confirmed statistically significant differences in 1 year survival among the planting season treatments $(p<0.01)[27]$. 
Table 2. Overview of linear mixed models used in this study.

\begin{tabular}{|c|c|c|c|c|c|c|c|c|}
\hline \multirow{2}{*}{ Model \# } & \multicolumn{3}{|c|}{ Response Variable } & \multicolumn{2}{|l|}{ Fixed Effects Parameters ${ }^{a}$} & \multirow{2}{*}{$\begin{array}{l}\text { Random Effect }^{b} \\
\text { Group in Stand }\end{array}$} & \multirow{2}{*}{$\begin{array}{l}\text { GLM }^{c} \\
\text { Family }\end{array}$} & \multirow{2}{*}{$\begin{array}{l}\text { GLM } \\
\text { Link }\end{array}$} \\
\hline & Type & Treatments & Year & & Stand & & & \\
\hline 1 & \multirow{3}{*}{ Survival \% } & All & 1 & $-1.23-0.04 \cdot X_{1}+0.57 \cdot X_{2}-19.66 \cdot X_{3}-3.46 \cdot X_{4}-16.74 \cdot X_{5}$ & 0.41 & - & Binomial & Logit \\
\hline 2 & & Dormant & 1 & $-1.23-0.04 \cdot \mathrm{X}_{1}+0.57 \cdot \mathrm{X}_{2}$ & 0.39 & - & Binomial & Logit \\
\hline 3 & & Dormant & 2.5 & $-1.95-0.25 \cdot X_{1}+0.16 \cdot X_{2}$ & 0.64 & - & Binomial & Logit \\
\hline 4 & \multirow{3}{*}{ Herbivory \% } & All & 1 & $0.90-0.25 \cdot X_{1}-0.72 \cdot X_{2}+0.97 \cdot X_{3}+0.41 \cdot X_{4}+0.87 \cdot X_{5}$ & 0.49 & - & Binomial & Logit \\
\hline 5 & & All & 1.5 & $0.90-0.25 \cdot X_{1}-0.72 \cdot X_{2}+0.97 \cdot X_{3}+0.41 \cdot X_{4}+1.0 X_{5}$ & 0.49 & - & Binomial & Logit \\
\hline 6 & & Dormant & 2.5 & $1.36-0.16 \cdot X_{1}-0.37 \cdot X_{2}$ & 0.43 & - & Binomial & Logit \\
\hline 7 & \multirow{2}{*}{ Growth $(\mathrm{cm})$} & Dormant (Height) & 1 & $5.1-2.64 \cdot X_{1}+0.92 \cdot X_{2}$ & 0.68 & $<0.01$ & - & - \\
\hline 8 & & Dormant (Diameter) & 1 & $0.26-0.07 \cdot X_{1}+0.02 \cdot X_{2}$ & $<0.01$ & 0.02 & - & - \\
\hline
\end{tabular}

Where: $X_{1}=$ Dormant $\cdot C W C(1$ or 0$), X_{2}=$ Dormant $P W C(1$ or 0$), X_{3}=$ Monsoon ( 1 or 0$), X_{4}=$ Monsoon.CWC $(1$ or 0$), X_{5}=$ Monsoon.PWC $(1$ or 0$) .{ }^{\text {a }}$ Fixed effects parameters for models $1-6$ are reported on the logit scale. ${ }^{b}$ Standard deviation for intercept-only random effects. ${ }^{\mathrm{c}}$ Generalized Linear Model. 
Abandoning the monsoon season analyses simplified the study design to a fully randomized balanced complete block design where dormant season planting groups received one of three vegetation management levels and each level was applied to five planting groups in each of the three stands. The average proportion of surviving seedlings in a dormant season planting group after 1 and 2.5 years was modeled as a function of vegetation management as a fixed effect, along with stand as a random effect intercept (Table 2, Models 2,3) using mixed-effects logistic regression fit by maximum likelihood via the lme4 package [26]. The main effect of vegetation management was tested with a likelihood ratio test. Tukey pairwise comparisons among vegetation management levels were conducted via the multcomp package [28].

\subsubsection{Herbivory}

Because herbivory was a pervasive cause of low initial survival in the study, analysis of herbivory rates among treatments became of interest. The average proportion of browsed seedlings in a planting group after years 1 and 1.5 were modeled as a function of vegetation management and planting season (with three and two levels respectively) and their interaction as fixed effects, along with the stand as a random effect intercept (Table 2, Models 4,5) using mixed-effects logistic regression fit by maximum likelihood via the lme4 package [26]. The planting season-vegetation management interaction was tested with a likelihood ratio test. In the case of a significant interaction term, the main effects were tested using Type II Wald tests via the car package; otherwise, Type III Wald tests were used [27]. Tukey pairwise comparisons among vegetation management levels were conducted via the multcomp package [28].

Herbivory beyond 1.5 years was analyzed only for the dormant season. Herbivory rates after 2.5 years ( 29 months) in the dormant planting were estimated similarly to 2.5 years survival, with the average proportion of browsed seedlings in a dormant season planting group modeled as a function of vegetation management as a fixed effect, along with stand as a random effect intercept (Table 2, Model 6) using mixed-effects logistic regression fit by maximum likelihood via the lme4 package [26]. The main effect of vegetation management was tested with a likelihood ratio test. Tukey pairwise comparisons among vegetation management levels were conducted via the multcomp package [28].

\subsubsection{Growth}

Growth was tracked for individual seedlings (both height and groundline diameter) in the study. Because first-year survival was poor for the monsoon planting, growth analyses were only performed for the dormant planting. Average individual seedling growth for dormant plantings after 1 year was modeled as a function of vegetation management as a fixed effect using mixed-effects linear regression fit by restricted maximum likelihood via the nlme package [29] (Table 2, Models 7, 8). Random effects were stand and planting group nested within stand as intercepts only. The main effect of vegetation management was tested with a likelihood ratio test. Tukey pairwise comparisons among vegetation management levels were conducted via the multcomp package [28].

\section{Results}

\subsection{Survival}

The study-wide average 1 year survival rate was 18\% (SE: 2.8) across all treatments. Figure 2A shows that 1-year survival was more strongly influenced by planting season than vegetation management. Average survival for the dormant planting was 27\% (SE: 4.9) across vegetation management treatments whereas the monsoon planting was $<1 \%$ (SE: 0.6 ), which was a statistically significant difference $(p<0.01)$. Given the poor first-year monsoon survival, comparisons of survival rates among vegetation management levels was only conducted for the dormant season plantings. Within the dormant season plantings, first-year survival varied among the vegetation treatments $(p=0.03)$, with the PWC treatment having the highest average survival (34\%, SE: 6.4$)$. Survival in the 
PWC treatment was statistically different from both the NWC $(p=0.03)$ and CWC $(p=0.02)$ treatments, which both had an average survival rate of approx. 22\% (SE: 5.2 ). Fixed effects parameter statistics for the various treatments are provided in Table 3.
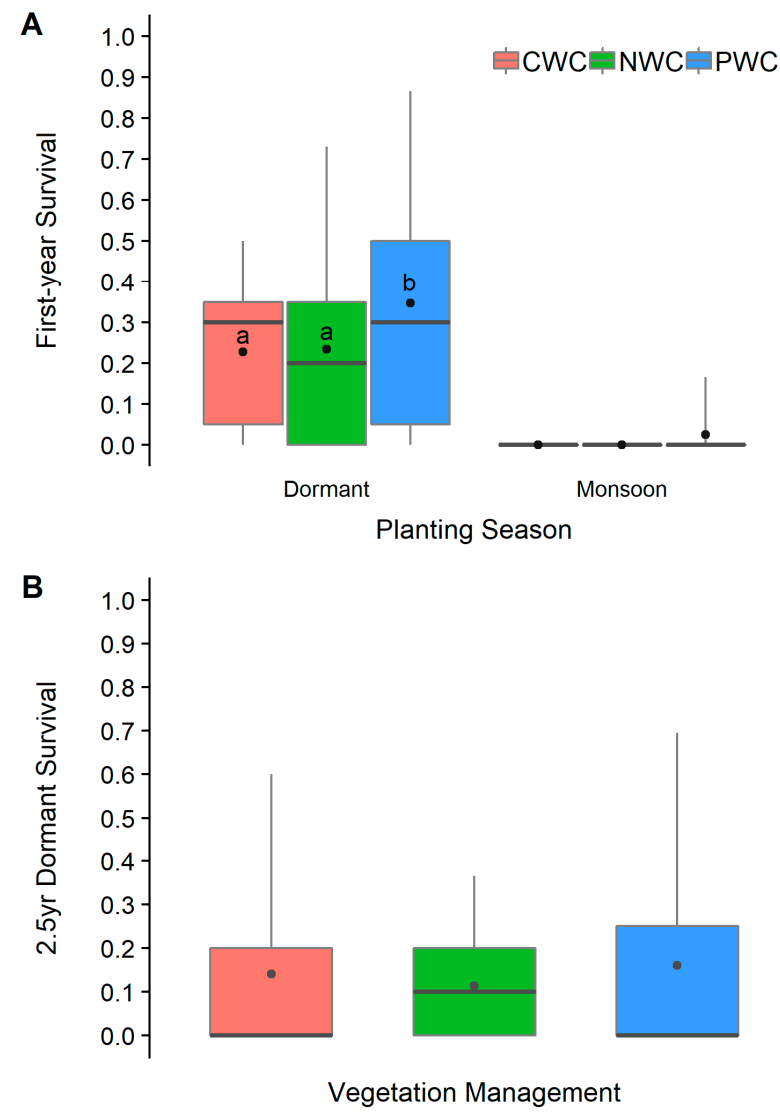

Figure 2. Survival rates of planted ponderosa pine seedlings in the Davis Mountains after 1 year for each planting season and vegetation management treatment combination (A) and 2.5 years for dormant season (B). Boxplots denote interquartile range, whiskers denote the 2.5 th and 97.5 th percentiles, grey horizontal line denotes the median, and black points denote the mean for each treatment. Treatments that share letters were not statistically different.

Table 3. Overview of fixed effect parameter statistics and model performance.

\begin{tabular}{cccccccc}
\hline \multirow{2}{*}{ Model } & Intercept & $\mathbf{X}_{\mathbf{1}}$ & \multicolumn{1}{c}{$\mathbf{X}_{\mathbf{2}}$} & $\mathbf{X}_{\mathbf{3}}$ & $\mathbf{X}_{\mathbf{4}}$ & $\mathbf{X}_{\mathbf{5}}$ & \multirow{2}{*}{ AIC } \\
\cline { 2 - 6 } & \multicolumn{7}{c}{$p$-Values } \\
\hline 1 & $<0.01$ & 0.89 & 0.03 & 0.96 & 0.99 & 0.96 & 259.9 \\
2 & $<0.01$ & 0.89 & 0.03 & - & - & - & 243.8 \\
3 & $<0.01$ & 0.48 & 0.62 & - & - & - & 187.8 \\
4 & $<0.01$ & 0.31 & $<0.01$ & $<0.01$ & 0.43 & 0.11 & 356.7 \\
5 & $<0.01$ & 0.31 & $<0.01$ & $<0.01$ & 0.43 & 0.07 & 353.6 \\
6 & $<0.01$ & 0.57 & 0.17 & - & - & - & 227.8 \\
7 & $<0.01$ & 0.03 & 0.40 & - & - & - & 737.6 \\
8 & $<0.01$ & 0.04 & 0.50 & - & - & - & -133.94 \\
\hline
\end{tabular}

Where: $X_{1}=$ Dormant $\cdot C W C(1$ or 0$), X_{2}=$ Dormant $P W C(1$ or 0$), X_{3}=$ Monsoon (1 or 0$), X_{4}=$ Monsoon.CWC $(1$ or 0$), X_{5}=$ Monsoon. PWC (1 or 0$)$.

After 2.5 years, average survival for the dormant planting had fallen to approx. $12 \%$ (SE: 2.9) across all vegetation management treatments (Figure 2B). Although statistically significant after 1 year, differences among vegetation management treatments faded by 2.5 years and were no longer statistically significant $(p=0.48)$. 
Mortality occurred more rapidly in the monsoon planting than the dormant planting (Figure 3A), although there was no obvious periodicity across treatments (Figure 3B). Field evidence indicated that approx. $13 \%$ (SE: 2.7) of the 1 year dormant planting mortality, or $10 \%$ of all planted seedlings, were lost to desiccation (Table 4). In the monsoon planting, $11 \%$ (SE: 3.4) of the 1 year mortality (and planted seedlings), were lost to desiccation, with little change at 1.5 years. In the dormant planting, desiccation caused about $12 \%$ (SE: 3.7 ) of the mortality (10\% of planted seedlings) after 1.5 and 2.5 years.
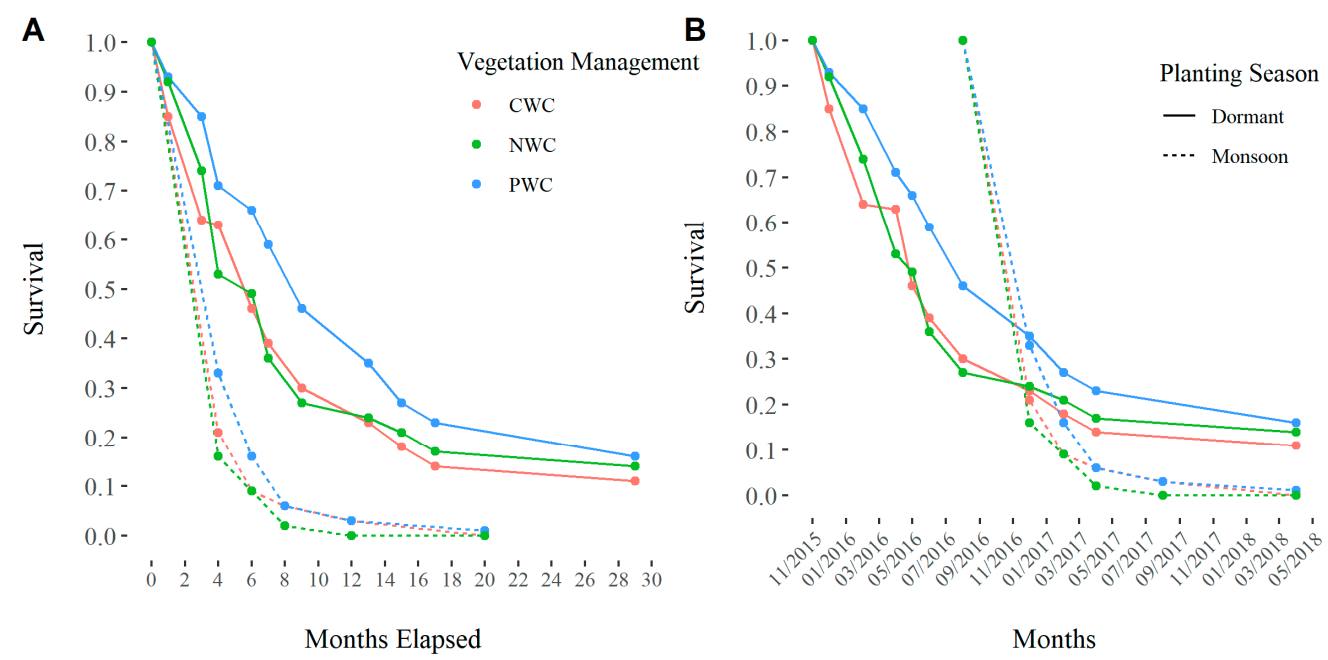

Figure 3. Longitudinal survival rates of planted ponderosa pine seedlings in the Davis Mountains as a function of time since planting (A) and study timeline (B).

Table 4. Apparent cause of death contingency table for planted ponderosa pine seedlings in the Davis Mountains in all planting season and vegetation management ${ }^{\text {a }}$ treatments.

\begin{tabular}{|c|c|c|c|c|c|c|}
\hline Time & $\begin{array}{l}\text { Planting } \\
\text { Season }\end{array}$ & $\begin{array}{l}\text { Vegetation } \\
\text { Management }\end{array}$ & Alive & Desiccation & Herbivory & Total \\
\hline & & & & number of $\mathrm{pl}$ & ed seedlings & \\
\hline \multirow{8}{*}{1 year } & \multirow{4}{*}{ Dormant } & NWC & $35(23 \%)$ & $10(07 \%)$ & 105 (70\%) & 150 \\
\hline & & CWC & $35(23 \%)$ & $18(12 \%)$ & $97(65 \%)$ & 150 \\
\hline & & PWC & $53(35 \%)$ & $16(11 \%)$ & $81(54 \%)$ & 150 \\
\hline & & & $123(27 \%)$ & $44(10 \%)$ & $283(63 \%)$ & 450 \\
\hline & \multirow{4}{*}{ Monsoon } & NWC & $0(00 \%)$ & $12(13 \%)$ & $78(87 \%)$ & 90 \\
\hline & & CWC & $0(00 \%)$ & $9(10 \%)$ & $78(90 \%)$ & 87 \\
\hline & & PWC & $2(03 \%)$ & $7(09 \%)$ & $71(89 \%)$ & 80 \\
\hline & & & $2(01 \%)$ & $28(11 \%)$ & $227(88 \%)$ & 257 \\
\hline \multirow{8}{*}{1.5 years } & \multirow{4}{*}{ Dormant } & NWC & $25(17 \%)$ & $11(07 \%)$ & $114(76 \%)$ & 150 \\
\hline & & CWC & $21(14 \%)$ & $19(13 \%)$ & $110(73 \%)$ & 150 \\
\hline & & PWC & $35(24 \%)$ & $17(11 \%)$ & $98(65 \%)$ & 150 \\
\hline & & & $81(18 \%)$ & $47(10 \%)$ & $322(72 \%)$ & 450 \\
\hline & \multirow{4}{*}{ Monsoon } & NWC & $0(00 \%)$ & $12(13 \%)$ & $78(87 \%)$ & 90 \\
\hline & & CWC & $0(00 \%)$ & $9(10 \%)$ & $78(90 \%)$ & 87 \\
\hline & & PWC & $1(01 \%)$ & $7(09 \%)$ & $72(90 \%)$ & 80 \\
\hline & & & $1(00 \%)$ & $28(11 \%)$ & $228(89 \%)$ & 257 \\
\hline \multirow{4}{*}{2.5 years } & \multirow{4}{*}{ Dormant } & NWC & $21(14 \%)$ & $11(07 \%)$ & $118(79 \%)$ & 150 \\
\hline & & CWC & $17(11 \%)$ & $19(13 \%)$ & $114(76 \%)$ & 150 \\
\hline & & PWC & $24(16 \%)$ & $18(12 \%)$ & $108(72 \%)$ & 150 \\
\hline & & & $62(14 \%)$ & $48(11 \%)$ & $340(76 \%)$ & 450 \\
\hline
\end{tabular}

${ }^{\mathrm{a}} \mathrm{NWC}=$ no weed control, $\mathrm{CWC}=$ chemical weed control, $\mathrm{PWC}=$ physical weed control. 


\subsection{Herbivory}

Most of the mortality (approx. 80\% of all planted seedlings) was herbivory (Table 4). Frequent observations of extensive burrows and mounds after planting and either a total lack of remnant roots or characteristic severe root damage on upright dead seedlings suggested pocket gophers (Geomyidae) were the usual browsers. Some herbivory from aboveground browsing was observed in all stands, but less frequently. In planting groups where herbivory occurred, it was usually extensive. Herbivory rates $\geq 70 \%$ were observed on approx. two-thirds of the planting groups after 1 year and a complete loss was the most common outcome (Figure 4).

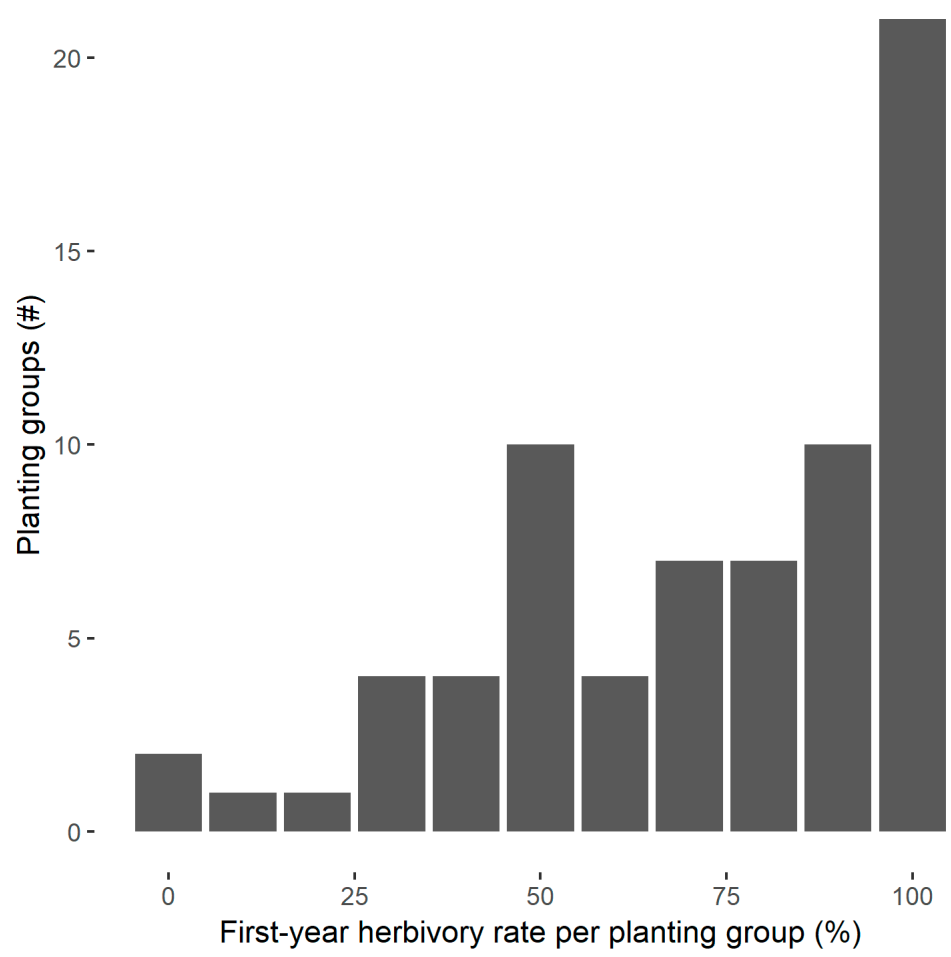

Figure 4. Frequency of first-year herbivory rates for individual planting groups ponderosa pine seedlings in the Davis Mountains. Herbivory rate per planting group refers to the proportion browsed (dead) seedlings within a planting group.

First-year herbivory rates varied among treatments, but without a significant planting season $\cdot$ vegetation management interaction $(p=0.27)$. Herbivory rates averaged $63 \%$ after 1 year in the dormant plantings and $88 \%$ in the monsoon plantings, which was a statistically significant difference $(p<0.01)$. There was also a statistically significant difference in first-year herbivory rates among vegetation management treatments $(p=0.04)$, but only PWC and NWC differed $(p=0.01)$.

By 1.5 years, differences in herbivory rates among planting seasons remained $(p<0.01)$ but vegetation management treatments had largely faded $(p=0.05)$. After 2.5 years, herbivory rates for the dormant plantings had risen to $76 \%$ (SE: 3.5 ) with a clear lack of statistical difference among vegetation management treatments $(p=0.39)$.

\subsection{Growth}

The average 1-year height growth for the dormant planting was $4.8 \mathrm{~cm}$ (SE: 0.8) but varied among vegetation management treatments $(p<0.01)$. Average height growth was $5.1 \mathrm{~cm}$ (SE: 0.9$)$ in NWC, $2.5 \mathrm{~cm}$ (SE: 0.9) in CWC and 6.1 (SE: 0.8) cm in PWC (Figure 5A). CWC height growth differed from both NWC $(p=0.03)$ and PWC $(p<0.01)$. PWC height growth did not differ from NWC $(p=0.40)$. The average 1-year groundline diameter growth was $0.25 \mathrm{~cm}$ (SE: 0.02), with differences among vegetation management treatments $(p=0.01)$. Average diameter growth was $0.26 \mathrm{~cm}$ (SE: 0.02$)$ 
in NWC, $0.19 \mathrm{~cm}$ (SE: 0.02) in CWC, and $0.28 \mathrm{~cm}$ (SE: 0.02) in PWC (Figure 5B). The CWC diameter growth differed from both NWC $(p=0.04)$ and PWC $(p<0.01)$. PWC and NWC did not differ $(p=0.50)$.

$$
\text { A }
$$
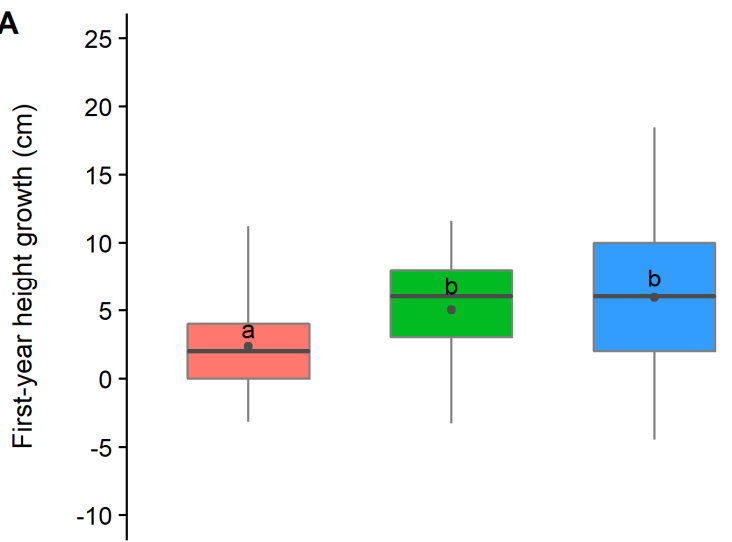

B

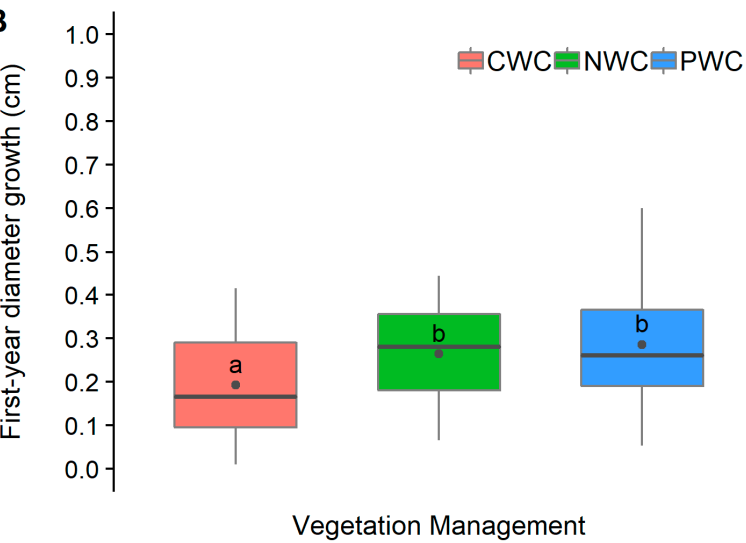

Figure 5. First-year height (A) and groundline diameter (B) growth of dormant season planted ponderosa pine in the Davis Mountains. Boxplots denote interquartile range, whiskers denote the 2.5th and 97.5th percentiles, white horizontal line denotes the median, and black points denote the mean for each treatment. Treatments that share letters were not statistically different.

\section{Discussion}

\subsection{Poor Survival and Herbivory Effects}

Survival was poor, similar to xeric, frequent-fire forests elsewhere in the US Southwest under similar conditions. Ouzts et al. [30] reported $25 \%$ survival for ponderosa pine seedlings after 5-8 years across several southwestern stands and $0 \%-12 \%$ in $38 \%$ of stands surveyed. The frequency of planting groups completely lost to herbivory suggests that it is the principal short-term obstacle to artificial regeneration on similar sites in the DMP where there is a documented population of pocket gophers [31-33]. Gopher herbivory of planted seedlings is common in many parts of the ponderosa pine range [34-36]. The study sites had several factors that lead to moderate or high gopher damage potential, including recent harvesting, well-drained soils, and low slopes [37]. Gopher soil disturbance has been associated with increased temperature and forb cover [38] and soil moisture [39], suggesting phenology may have contributed to the more rapid herbivory observed in the monsoon season plantings. Survival in the study was comparable to a report by Hooven [35] after 1 year in areas occupied by pocket gophers. Hooven [35] reported that survival rates had dropped to $12 \%$ after five years in those areas compared to $87 \%$ in areas without pocket gophers.

Successful restoration may hinge on identifying treatments to reduce herbivory, particularly in areas with loamy soils where herbivory was prevalent. Unfortunately, common control strategies are seldom effective or feasible without intensive maintenance or expense [35,40]. Remoteness and access 
limitations within the DMP pose considerable barriers to any control strategies requiring intensive maintenance. Direct population reductions (e.g., rodenticide) or mechanically reducing access to seedlings are most effective [37], although their use may be restricted in some areas. The higher survival and lower initial herbivory rates found in the PWC treatment may be partly attributable to some deterrence by the landscaping staples that fasten the fibrous mats around the seedlings, but any effect was short-lived. Herbivory occurred in almost all planting groups and tended to be extensive where it occurred. It is possible a more scattered planting pattern may reduce herbivory and additional research into herbivory reduction alternatives and whether spatial arrangement of planted seedlings, e.g., clustered vs scattered, is associated with herbivory rates is warranted.

Absent effective deterrence, a more dubious option may be an attempt to overcompensate herbivory losses by planting more seedlings than are ultimately desired. Engeman and Witmer [37] suggest this approach could have moderate to high efficacy. Based on study survival rates, that would require 5-10 times more seedlings than ultimately desired. This highlights the second obstacle to restoring ponderosa pine in the DMP: the scarcity of seedlings from both natural and local artificial sources. To date, cone and seed collection efforts have been limited to trees and stands within the immediate region of the study. The recent lack of natural regeneration and scarce availability of locally-sourced containerized seedlings will continue to complicate restoration efforts even as continued research aims to improve survival and growth of outplanted seedlings. This is in stark contrast to portions of the ponderosa pine range where excessive natural reproduction densities are often a concern [41].

\subsection{Planting Season and Vegetation Management}

The US Forest Service has reported success with mid-summer through early-fall plantings coinciding with the monsoon season in the states of Arizona and New Mexico, using nursery protocols tailored for "hot-planting" (Patterson, P.E. and Youtz, J.A. pers. comm.). This strategy aims to take advantage of moderated conditions such as higher soil moisture, higher relative humidity, and little to no wind, when available. The monsoon study seedlings were not raised for hot-planting, and their poor performance suggests that, without appropriate nursery protocols, monsoon planting in the DMP is not advisable. The planting season effects were confounded by differences in planting stock age (1-0 vs. 2-0), which was somewhat unavoidable in the implementation of the study, but the condition and survival of the locally-sourced 2-0 containerized seedlings (monsoon) were poor, even in the nursery. This suggests improved seed sources and nursery practices may offer some mitigation for monsoon planting. Another caveat was herbivory, which was pervasive across treatments, but greater still in the monsoon season planting. The $88 \% 1$ year herbivory rate in the monsoon season planting limits the conclusions regarding physiological effects of planting season on artificial regeneration in the DMP. Additional research into the timing of planting is recommended. In the immediate future, efforts may benefit by planting 1-0 containerized seedlings abundantly during favorable climatic windows.

In addition to some early advantages in survival and herbivory rates, seedlings in the PWC treatment showed statistically superior growth when compared to those in the CWC treatment, making PWC a potential early recommendation if vegetation management treatments are pursued. Although there was no statistical difference in growth provided by the PWC compared to NWC, the benefits of vegetation management to early survival and growth have been reported elsewhere, particularly following fire $[1,23,42]$. It is possible that nominal height growth advantages will eventually accumulate into meaningful differences as the seedlings continue to interact with the herbaceous layer [23]. However, it is not known if that effect will persist, or for how long. It is possible that alternative timings, rates, or herbicides could provide more efficacious chemical control while avoiding the adverse impacts on ponderosa seedling growth observed in the study. Despite precautionary efforts to minimize damage to the planted dormant season ponderosa seedlings during herbicide application, a few seedlings exhibited evidence of herbicide damage. Ponderosa pine has been documented as sensitive to several herbicides, including the one used in this study, despite being labeled for 
herbaceous weed control for ponderosa pine. While the biological significance of the observed differences in height or diameter growth at this point in the study is minor, the comparative height and diameter development trends of the seedlings across treatments are worth monitoring in the future.

\subsection{Continuing Restoration Considerations}

The continued scarcity of naturally-occurring ponderosa pine seedlings through five years post-wildfire is somewhat troubling. Given the sporadic establishment tendency, which requires specific climatic conditions across several consecutive years, it may still be possible for reproduction density to improve under favorable conditions [18,43-45]. However, Roccaforte et al. [46] found that $57 \%$ of severely burned southwestern stands had no reproduction present up to 12 years post-fire. Ponderosa stands that do not exhibit robust recovery following high-severity fires risk transformation to alternative vegetation states $[11,19]$. Objective measures of fire severity for the wildfires that burned through the DMP are lacking, but they did coincide with a period of drought. Synchronous high-severity fires and drought likely exacerbate regeneration limitations at a time when cohort establishment is paramount [45,47]. Moreover, interactions between wildfire, insect disturbances, and unfavorable climate conditions at the trailing edge of a species range can result in lasting regeneration difficulties [20]. Less than half the ponderosa pine survived according to TFS estimates and rates varied spatially, with several survivors in some stands and complete losses in others. Many stands have at least a few scattered survivors. Reproduction density decreases exponentially with distance from surviving seed-bearing trees [48], suggesting that development of a reliable artificial regeneration strategy may be critical for ponderosa pine to remain a keystone species in the near future on the most affected sites. Given the susceptibility of seedlings and saplings to wildfire and the buildup of surface fuels in the herbaceous layer, restoration strategies must extend beyond regeneration establishment [49].

\section{Conclusions}

The results of the study indicate that early survival of ponderosa pine seedlings was statistically greater for dormant season plantings than monsoon season plantings. Herbivory was the primary cause of mortality in the study and there were statistically higher rates of herbivory for monsoon season plantings than dormant season plantings over the course of 1.5 years. Vegetation management treatments influenced early growth, survival, and herbivory rates. Growth in the CWC treatments was statistically lower than the other two vegetation management treatments, The PWC treatment showed some early statistical advantages in 1 year survival and herbivory deterrence, but all vegetation management treatments had similar survival and herbivory results after 2.5 years.

The study results are a step toward science-based silvicultural guidelines for ponderosa pine restoration in the Davis Mountains. Although herbivory has been identified as the principal short-term obstacle to artificially regenerating ponderosa pine in the DMP, the larger question of recovery in this isolated population, particularly if local climatic conditions become increasingly unfavorable, remains. Critical challenges are the identification of target conditions that are both appropriate and achievable and the suite of management options, silvicultural treatments, and timing needed to meet them [10]. Such questions and challenges are expected to become increasingly prevalent as changing climatic conditions and disturbance regimes influence forest ecology and management in forest ecosystems around the world [50-52].

Author Contributions: Conceptualization, L.A.V., J.H., J.R. and J.M.G.; methodology, L.A.V., J.M.G., J.H. and J.R.; formal analysis, L.A.V.; writing—original draft preparation, L.A.V.; writing-review and editing, J.M.G., J.H. and J.R.; supervision, J.M.G., J.R.; project administration, J.H. and J.R.; funding acquisition, J.M.G., J.H. and J.R.

Funding: This research was funded by the U.S. Forest Service Southern Research Station and the Texas A\&M Forest Service. The APC was funded by U.S. Forest Service Southern Research Station.

Acknowledgments: This effort was supported by the Texas A\&M Forest Service, The Nature Conservancy, and U.S. Forest Service Southern Research Station. The authors acknowledge T. Boggus and B. Oates of the Texas 
A\&M Forest Service for their essential support. Help from C. Reemts, D. Hisler, and G. Crow of The Nature Conservancy is appreciated. Several Texas A\&M Forest Service staff including E. Driscoll, R. Edmonson, M. Merrit, R. McGregor, J. Motsinger, A. Geppart, B. Buckner, D. Duncum, M. Borski, M. Downs, W. Powell, M. Carter, M. Cunningham, D. Albatal, E. Borman, K. Dowdy, J. Webb, Z. Jones, C. Bales, and O. Mestas were indispensable. M.G. Olson and L.S. Pile improved early manuscript drafts, as did comments from anonymous reviewers.

Conflicts of Interest: The authors declare no conflict of interest. The funders had no role in the design of the study; in the collection, analyses, or interpretation of data; in the writing of the manuscript, or in the decision to publish the results.

\section{References}

1. Oliver, W.W.; Ryker, R.A. Ponderosa pine. In Silvics of North America; Burns, R.M., Honkala, B.H., Eds.; United States Department of Agriculture Forest Service: Washington, DC, USA, 1990; pp. 413-424.

2. Willyard, A.; Gernandt, D.S.; Potter, K.; Hipkins, V.; Marquardt, P.; Mahalovich, M.F.; Langer, S.K.; Telewski, F.W.; Cooper, B.; Douglas, C.; et al. Pinus ponderosa: A checkered past obscured four species. Am. J. Bot. 2017, 104, 161-181. [CrossRef] [PubMed]

3. Callaham, R.Z. Pinus Ponderosa: A Taxonomic Review with Five Subspecies in the United States; United States Department of Agriculture Forest Service, Pacific Southwest Research Station: Albany, CA, USA, 2013.

4. Ponderosa Pine. Available online: https://plants.usda.gov/core/profile?symbol=PIPOS (accessed on 6 February 2019).

5. Cleland, D.T.; Freeouf, J.A.; Keys, J.E.; Nowacki, G.J.; Carpenter, C.A.; Mcnab, W.H. Ecological Subregions: Sections and Subsections for the Conterminous United States; United States Department of Agriculture Forest Service: Washington, DC, USA, 2007.

6. Hinckley, L.C. The vegetation of the Mount Livermore area in Texas. Am. Mid. Nat. 1944, 32, $236-250$. [CrossRef]

7. Bataineh, M.M.; Oswald, B.P.; Bataineh, A.L.; Farrish, K.W.; Coble, D.W.; Edminster, C.B. Plant communities associated with Pinus ponderosa forests in the sky islands of the Davis Mountains, Texas. J. Torr. Bot. Soc. 2007, 134, 468-478. [CrossRef]

8. Poulos, H.; Camp, A.E.; Gatewood, R.G.; Loomis, L. A hierarchical approach for scaling forest inventory and fuels data from local to landscape scales in the Davis Mountains, Texas, USA. For. Ecol. Manag. 2007, 244, 1-15. [CrossRef]

9. Poulos, H.M.; Camp, A.E. Topographic influences on vegetation mosaics and tree diversity in the Chihuahuan Desert Borderlands. Ecology 2010, 91, 1140-1151. [CrossRef]

10. Reynolds, R.T.; Sanchez Meador, A.J.; Youtz, J.A.; Nicolet, T.; Matonis, M.S.; Jackson, P.L.; Delorenzo, D.G.; Graves, A.D. Restoring Composition and Structure in Southwestern Frequent-Fire Forests: A Science-Based Framework for Improving Ecosystem Resiliency; United States Department of Agriculture Forest Service, Rocky Mountain Research Station: Fort Collins, CO, USA, 2013.

11. Millar, C.I.; Stephenson, N.L. Temperate forest health in an era of megadisturbance. Science 2015, 349, 823-826. [CrossRef] [PubMed]

12. Poulos, H.M.; Villanueva Diaz, J.; Cerano Paredes, J.; Camp, A.E.; Gatewood, R.G. Human influences on fire regimes and forest structure in the Chihuahuan Desert Borderlands. For. Ecol. Manag. 2013, 98, 1-11. [CrossRef]

13. Bataineh, M.M. Stand Structure of Piñon-Juniper Communities in the Sky Islands of the Davis Mountains, Texas. Ph.D. Dissertation, Stephen F. Austin State University, Nacogdoches, TX, USA, 2006.

14. Prestemon, J.; Pye, J.; Barbour, J.; Smith, G.R.; Ince, P.; Steppleton, C.; Xu, W.U.S. Wood-Using Mill Locations-2005. Available online: http://www.srs.fs.usda.gov/econ/data/mills (accessed on 7 February 2017).

15. Mount Locke Cooperative Precipitation Data. Available online: https://www.weather.gov/maf/cli_maf_ coop_annprecip_mount_locke (accessed on 1 October 2016).

16. Mount Locke, TX Average of Average Temperature. Available online: https://wrcc.dri.edu/cgi-bin/ cliMAIN.pl?tx6104 (accessed on 1 October 2016).

17. Bataineh, M.M. Community Classification in the Davis Mountains Sky Islands: Ponderosa Pine (Pinus Ponderosa Laws) and Adjacent Communities. Master's Thesis, Stephen F. Austin State University, Nacogdoches, TX, USA, 2004. 
18. Savage, M.; Brown, P.B.; Feddema, J. The role of climate in a pine forest regeneration pulse in the southwestern United States. Ecoscience 1996, 3, 310-318. [CrossRef]

19. Savage, M.; Mast, J.N. How resilient are southwestern ponderosa pine forests after crown fires? Can. J. For. Res. 2005, 35, 967-977. [CrossRef]

20. Renwick, K.M.; Rocca, M.E.; Stohlgren, T.J. Biotic disturbance facilities range shift at the trailing but not the leading edge of lodgepole pine's altitudinal distribution. J. Veg. Sci. 2016, 27, 780-788. [CrossRef]

21. Ozanne, C.M.P.; Anhuf, D.; Boulter, S.L.; Keller, M.; Kitching, R.L.; Körner, C.; Meinzer, F.C.; Mitchell, A.W.; Nakashizuka, T.; Silva Dias, P.L.; et al. Biodiversity meets the atmosphere: A global view of forest canopies. Science 2003, 301, 183-186. [CrossRef] [PubMed]

22. Nakamura, A.; Kitching, R.L.; Cao, M.; Creedy, T.J.; Fayle, T.M.; Freiberg, M.; Hewitt, C.N.; Itioka, T.; Pin Koh, L.; Malhi, K.; et al. Forests and Their Canopies: Achievements and horizons in canopy science. Trends Ecol. Evol. 2017, 32, 438-451. [CrossRef] [PubMed]

23. Schubert, G.H. Silviculture of Southwestern Ponderosa Pine: The Status of Our Knowledge; United States Department of Agriculture Forest Service, Rocky Mountain Research Station: Fort Collins, CO, USA, 1974.

24. Turner, A. Soil Survey of Jeff Davis County, Texas. Available online: https://www.nrcs.usda.gov/Internet/ FSE_MANUSCRIPTS/texas/TX243/0/Jeff\%20Davis.pdf (accessed on 1 October 2016).

25. R Development Core Team. R: A Language and Environment for Statistical Computing; R Version 3.3.2; R Foundation for Statistical Computing: Vienna, Austria, 2016.

26. Bates, D.; Maechler, M.; Bolker, B.; Walker, S. Fitting linear mixed-effects models using lme4. J. Stat. Soft. 2015, 67, 1-48. [CrossRef]

27. Fox, J.; Weisberg, S. An (R) Companion to Applied Regression, 2nd ed.; Sage: Thousand Oaks, CA, USA, 2011.

28. Hothorn, T.; Bretz, F.; Westfall, P. Simultaneous inference in General Parametric Models. Biom. J. 2008, 50, 346-363. [CrossRef] [PubMed]

29. Pinheiro, J.; Bates, D.; Debroy, S.; Sarkar, D.; R Core Team. Nlme: Linear and Nonlinear Mixed Effects Models. R Package Version 3.1-128. Available online: http:/ /CRAN.R-project.org/package=nlme (accessed on 1 October 2016).

30. Ouzts, J.; Kolb, T.; Huffman, D.; Sánchez Meador, A. Post-fire ponderosa pine regeneration with and without planting in Arizona and New Mexico. For. Ecol. Manag. 2015, 354, 281-290. [CrossRef]

31. Davis, W.B.; Buechner, H.K. Pocket gophers (Thomomys) of the Davis Mountains, Texas. J. Mammal. 1946, 27, 265-271. [CrossRef]

32. Reichman, O.J.; Baker, R.J. Distribution and movements of two species of pocket gophers (Geomyidae) in an area of sympatry in the Davis Mountains, Texas. J. Mammal. 1972, 53, 21-33. [CrossRef]

33. Williams, S.L.; Baker, R.J. Vagility and local movements of pocket gophers (Geomyidae: Rodentia). Am. Mid. Nat. 1976, 96, 303-316. [CrossRef]

34. Dingle, R.W. Pocket gophers as a cause of mortality in eastern Washington pine plantations. J. For. 1956, 54, 832-835.

35. Hooven, E.F. Pocket gopher damage on ponderosa pine plantations in southwestern Oregon. J. Wild. Manag. 1971, 35, 346-353. [CrossRef]

36. Barnes, V.G., Jr. Survival and growth of ponderosa pine seedlings injured by pocket gophers. Tree Plant. Notes 1978, 29, 20-23.

37. Engeman, R.M.; Witmer, G.W. Integrated management tactics for predicting and alleviating pocket gopher (Thomomys spp.) damage to conifer reforestation plantings. Int. Pest Manag. Rev. 2000, 5, 41-55. [CrossRef]

38. Lynn, J.S.; Canfield, S.; Conover, R.R.; Keene, J.; Rudgers, J.A. Pocket gopher (Thomomys talpoides) soil disturbance peaks at mid-elevation and is associated with air temperature, forb cover, and plant diversity. Arct. Antarct. Alp. Res. 2018, 50. [CrossRef]

39. Millar, M.A. Seasonal trends in burrowing of Pocket Gophers (Thomomys). J. Mammal. 1948, 29 , 38-44. [CrossRef]

40. Godfrey, M.E.R. A novel strategy for pocket gopher control. In Eighth Great Plains Wildlife Damage Control Workshop Proceedings; United States Department of Agriculture Forest Service, Rocky Mountain Forest and Range Experiment Station: Fort Collins, CO, USA, 1988; pp. 103-107.

41. Shepperd, W.D.; Battaglia, M.A. Ecology, Silviculture, and Management of Black Hills Ponderosa Pine; United States Department of Agriculture Forest Service, Rocky Mountain Research Station: Fort Collins, CO, USA, 2002. 
42. Castro, J.; Leverkus, A.B. Effect of herbaceous layer interference on the post-fire regeneration of a serotinous pine (Pinus pinaster Aiton) across two seedling ages. Forests 2019, 10, 74. [CrossRef]

43. Maguire, W.P. Are ponderosa pine cone crops predictable? J. For. 1956, 54, 778-779.

44. Petrie, M.D.; Wildeman, A.M.; Bradford, J.B.; Hubbard, R.M.; Lauenroth, W.K. A review of precipitation and temperature control on seedling emergence and establishment for ponderosa and lodgepole pine forest regeneration. For. Ecol. Manag. 2016, 361, 328-338. [CrossRef]

45. Petrie, M.D.; Bradford, J.B.; Hubbard, R.M.; Lauenroth, W.K.; Andrews, C.M.; Schlaepfer, D.R. Climate change may restrict dryland forest regeneration in the 21st century. Ecology 2017, 98, 1548-1559. [CrossRef]

46. Roccaforte, J.P.; Fulé, P.Z.; Walker Chancellor, W.; Laughlin, D.C. Woody debris and tree regeneration dynamics following severe wildfires in Arizona ponderosa pine forests. Can. J. For. Res. 2012, 42, 593-604. [CrossRef]

47. Savage, M.; Mast, J.N.; Feddema, J.J. Double whammy: High-severity fire and drought in ponderosa pine forests of the Southwest. Can. J. For. Res. 2013, 43, 570-583. [CrossRef]

48. Chambers, M.E.; Fornwalt, P.J.; Malone, S.L.; Battaglia, M.A. Patterns of conifer regeneration following high severity wildfire in ponderosa pine-dominated forests of the Colorado Front Range. For. Ecol. Manag. 2016, 378, 57-67. [CrossRef]

49. Battaglia, M.; Smith, F.W.; Shepperd, W.D. Predicting mortality of ponderosa pine regeneration after prescribed fire in the Black Hills, South Dakota, USA. Int. J. Wild. Fire 2009, 18, 176-190. [CrossRef]

50. Guldin, J.M. Silvicultural options in forests of the southern United States under changing climatic conditions. New For. 2019, 50, 71-87. [CrossRef]

51. Linder, M.; Maroschek, M.; Netherer, S.; Kremer, A.; Barbati, A.; Garcia-Gonzalo, J.; Seidl, R.; Delzon, S.; Corona, P.; Kolström, M.; et al. Climate change impacts, adaptive capacity, and vulnerability of European forest ecosystems. For. Ecol. Manag. 2010, 259, 698-709. [CrossRef]

52. Fuhrer, J.; Beniston, M.; Fischlin, A.; Frei, C.; Goyette, S.; Jasper, K.; Pfister, C. Climate risks and their impact on agriculture and forests in Switzerland. Clim. Chang. 2006, 79, 79-102. [CrossRef]

(C) 2019 by the authors. Licensee MDPI, Basel, Switzerland. This article is an open access article distributed under the terms and conditions of the Creative Commons Attribution (CC BY) license (http:/ / creativecommons.org/licenses/by/4.0/). 